\title{
Parents' Decision-making for Childhood Immunization and Prevention of Childhood Diseases - A Cross-Sectional Survey
}

Jonas KEMEUGNI NGANDJON ( $\sim$ kjonas25@yahoo.fr )

University of Witten / Herdecke

Alfred Laengler

University of Witten / Herdecke

Thomas Ostermann

University of Witten / Herdecke

Virgile Kenmoue

Université des Montagnes

\section{Research Article}

Keywords: Community-based Programs, Health education, Herd immunity, Health-seeking behavior, Vaccination status, Community-related framework, Vaccination program, Vaccination coverage, Health Belief Model

Posted Date: November 23rd, 2021

DOI: https://doi.org/10.21203/rs.3.rs-1047244/v1

License: (1) This work is licensed under a Creative Commons Attribution 4.0 International License. Read Full License 


\section{Abstract \\ Background}

The childhood vaccination program (EPI) is claimed by the World Health Organization (WHO) to be the most cost-effective intervention to reduce child mortality. Therefore, in low-income countries governments and health authorities invest in vaccination programs to reach herd immunity. However, despite the resources allocated to the EPI, epidemics preventable through vaccines are still reported in these countries. In Cameroon, the Foumbot district in the West region has witnessed measles epidemics since 2010 and in 2013 a polio outbreak was reported.

\section{Methods}

The design of this study is a cross-sectional survey. A total of 160 mothers of children between the ages of 12 to 23 months were selected by simple random sampling technique. Pre-tested structured questionnaire was used for data collection. Data was analyzed using SPSS statistical software.

\section{Results}

The outcome of this survey shows that $60 \%$ of the children studied were completely vaccinated, $37.75 \%$ were partially vaccinated, and $1.25 \%$ had not received any vaccine. The logistic regression analysis shows that a poor knowledge of infectious diseases $(\mathrm{OR}=0.3)$ was a significant predictor of partial and no vaccination status in children.

\section{Conclusion}

Parents' decision-making for EPI was based on the information and experiences available in the community. Therefore, parents who are poorly educated on VPDs and living in a community with missing information and misinformation about vaccination will probably not complete the EPI. Public health authorities should invest in health education programs with the goal of developing skills for healthseeking behavior in individuals and communities.

\section{Background}

Prevention of children of diseases is the primary concern of pediatrics [1][3][4]. Since 1974, in order to reach herd immunity, the WHO (World Health Organization) has been motivating health authorities all around the world to invest in the EPI (Expanded Program on Immunization) to ensure vaccination of children around the world against vaccine-preventable childhood diseases (VPDs). Six vaccinepreventable diseases are recommended by the EPI: tuberculosis, polio, diphtheria, tetanus, measles, and pertussis [2]. In 2014, the herd immunity threshold in low-income countries was still below the $92-95 \%$ set 
by the WHO for VPDs except the BCG vaccine [22]. In Cameroon, the proportion of children below 2 years of age who are completely vaccinated for all recommended childhood vaccines [7][27][28] is still well below the target $80 \%$ of eligible children targeted by the Cameroonian government [11]. In September 2013, many cases of paralysis were reported in Foumbot district and Malentuen district in Cameroon. The Genotyping of the viruses showed that a similar virus (Wild Poliomyelitis Virus) affected all the children [12]. Interestingly, the affected children in Cameroon had never been outside the country. The virus genotype linked to the outbreak shows a parenthood to the poliovirus observed in Chad in 2011 [23].

The Foumbot district is a place at risk because of the outbreak. The district hosts one of the largest border fresh-food markets in Cameroon where people from all parts of the country and neighboring countries of Cameroon such as Niger, Chad, Central African Republic, Congo, Gabon, Equatorial Guinea, and Nigeria interact. The risk of expansion of the poliovirus to other parts of the country and to the neighboring countries is high. The parents of the first confirmed cases were farmers and gardeners who used to visit markets in Malentuen [12]. Although vaccination programs to eradicate measles around the country had already been implemented, a proliferation of measles was reported in nine health districts including the Foumbot district, [24]. Despite the financial resources allocated to the EPI to achieve herd immunity, VPDs remain a health care concern in Cameroon. The sole provision of vaccination does not guarantee herd immunity throughout the country [7][27]. Only the BCG coverage, which is given at birth, is above $90 \%$. The coverage of other vaccines in children is still far below $80 \%$ expected in all health districts. [7][11]. Based on actual experiences gained by vaccination practice in each region or community, it is possible to define the causes of reticence to the vaccination [14][17][18][41][29][30][31]. Therefore, programs leading to a higher prevention of infectious diseases in the population can only be defined, once the underlying reasons for the refusal and/or the interruption of the vaccination program are clearly identified. This study identifies, examines the factors affecting complete childhood vaccination in Foumbot district.

\section{Methods}

\section{Study area}

The Foumbot district covers an area of about $1000 \mathrm{~km}^{2}$. The district is rural and located in the Noun Division, West region of Cameroon. In 2013, the health district estimated the population to be 62,776 inhabitants (from the 2013 Census), the majority being Bamum. The predominant religion is Islam. Farming is the main occupation. The district hosts the most important fresh food market in the western region and is divided into eleven health communities, which provide EPI to the local population.

\section{Study design}

A cross-sectional survey of parents of children aged 12 to 23 months was performed from $1^{\text {st }}$ July to $31^{\text {st }}$ October 2014. This included a questionnaire to record the characteristics of mothers and children, and to evaluate maternal knowledge about vaccination. Only parents of the children were interviewed. Survey 
participants were selected randomly according to the WHO vaccination coverage cluster survey sampling [5][6][8][10]. The vaccination coverage has been evaluated by means of the vaccination booklet and EPI register. A child was said to be completely vaccinated if he had received all of the vaccines recommended by the EPI by the time he was selected for the survey.

\section{Sample size determination}

Using the sample size calculation methodology presented in the WHO Immunization Coverage Cluster Survey Reference Manual (WHO/IVB/04.23), the sample size required was determined using the coverage of $64 \%$

obtained in the western region, a precision of $\pm 10 \%$, a type 1 error of $10 \%$ and a design effect of 1.5 , in conformity with the standard WHO methodology [6][8]. Thus, the calculated minimum number of children required was 147.

\section{Participants}

During the investigation, data from 160 children and 160 parents were collected in the district randomly. The sampling process was performed according to the simple random sample (SRS) method [5][6]. The first household was randomly chosen from each selected cluster. Each household was chosen randomly, such that each household had the same probability in the cluster of being chosen during the sampling process [9]. The sampling technique applied allows the researcher to perform the evaluation with a sample that is representative. From this sample, statistical values have been generated to be extrapolated to the whole population of the Foumbot health district.

\section{Data analysis}

The data was collected by trained nurses using a French structured questionnaire. The structured questionnaire was adopted from the Demographic Health Survey of Cameroon [7]. The content of the questionnaire included: sociodemographic characteristics, questions related to parents and child health services, parents' perception about vaccination, parents' knowledge about VPDs. The vaccines received by the child were obtained from the vaccination card or through the vaccination history of the child reported by the parent. Prior to data collection, the questionnaire was pre-tested on $5 \%$ of the sample on a similar population.

The data from the interview was coded and entered into a computer database using Microsoft Office Excel 2010. Descriptive statistics were performed by means of EPI info 3.5.4 statistical software program to analyze the sample, to check the association of each independent variable with the complete vaccination. For this purpose, the odds ratios were calculated along with $95 \%$ confidence intervals $(\mathrm{Cl})$ and the $\mathrm{p}$-value from the Fisher's exact test. The analysis of the factors associated with vaccine incompleteness was carried out by means of the statistical software program SPSS according to a multivariate logistic regression model of the "forward" type: the first was a bivariate analysis which allowed us to obtain raw odds ratios for each one. of the variables with their $95 \%$ confidence intervals 
and their $P$ values. The variables that obtained a $p$ value $<0.5$ were statistical significant and were all entered into a multivariate logistic regression model to control for confounding factors and to determine which characteristics are independent predictors of the child's vaccination status [Table 3].

\section{Ethical clearance}

This study obtained the authorization of the Faculty of Medicine of the Université des Montagnes and the health authorities of the Foumbot district to be carried out. Verbal informed consent was required for each participant prior to the administration of the questionnaire.

\section{Findings And Childhood Vaccination Status \\ Childhood Vaccination Coverage}

\begin{tabular}{|c|c|c|c|c|c|c|}
\hline \multirow[t]{2}{*}{ Vaccine } & \multirow{2}{*}{$\begin{array}{c}\text { Case } \\
\text { Present study } \\
(n=160)\end{array}$} & \multirow{2}{*}{$\begin{array}{c}\text { Percentage } \\
\text { Present study } \\
(\mathrm{n}=160) \\
\%\end{array}$} & \multicolumn{2}{|l|}{ DHS (2011) } & \multicolumn{2}{|c|}{ WHO (2014) } \\
\hline & & & $\begin{array}{l}\text { West Region, Cameroon } \\
\qquad \begin{array}{c}(\mathrm{n}=2265) \\
\%\end{array}\end{array}$ & $\begin{array}{l}\text { Woldwide } \\
\text { Cameroon } \\
(\mathrm{n}=272) \\
\%\end{array}$ & Africa & $\%$ \\
\hline BCG & 158 & 98.8 & 87.1 & 95.9 & 91 & 84 \\
\hline Polio 0 & 158 & 98.8 & 71.7 & 84.4 & & \\
\hline DPT 1 & 144 & 90 & 85.5 & 94.4 & & \\
\hline DPT 2 & 134 & 83.8 & 78.3 & 87 & & \\
\hline DPT 3 & 125 & 78.1 & 68.4 & 75.5 & 86 & 77 \\
\hline OPV 1 & 143 & 89.4 & 93.3 & 92.5 & & \\
\hline OPV 2 & 134 & 83.8 & 85.5 & 87.5 & & \\
\hline OPV 3 & 124 & 77.5 & 69.8 & 76.6 & 86 & 77 \\
\hline VAA (Yellow Fever) & 101 & 63.1 & 69.3 & 77.7 & & \\
\hline VAR (Measles) & 101 & 63.1 & 70.6 & 79.8 & 56 & 11 \\
\hline Not vaccinated & 2 & 1.25 & 4.5 & 2.3 & & \\
\hline Completely vaccinated & 96 & 60 & 52.1 & 62.9 & & \\
\hline
\end{tabular}

Table 1: Vaccination coverage from Foumbot district for each antigen compared to latest data for Cameroon from WHO and Sociodemographic Health Survey (DHS)

\begin{tabular}{lc}
\hline Health facilities & Number of professional in charge of the vaccination \\
\hline CSI Kwen Baigom & 3 \\
Hôpital EEC Baigom & 1 \\
CSI Mbanjou & 2 \\
CSI Mbantou & 3 \\
CSP St blaise & 1 \\
Hôpital district foumbot & 4 \\
\hline
\end{tabular}

Table 2: Vaccination staff in the Foumbot district, 2014 
The vaccination status of the child was established by the records in the vaccination booklet, the records in the EPI registration or by the presence of scar in the case of BCG. In the 5 clusters, a total of 160 households were surveyed. It was found that $96(60 \%)$ children had received complete vaccination by the age of two. On the other hand, $62(38.75 \%)$ had received partial vaccination and $2(1.25 \%)$ had not received any vaccine. The dropout rate between the initial vaccine BCG or OPV 0 and the final vaccine measles is quite high with $36 \%$; that means, over one third of the children were unable to complete the vaccination program [Table 1]. 


\begin{tabular}{|c|c|c|c|c|c|c|c|}
\hline \multirow[t]{2}{*}{ Factors } & \multirow{2}{*}{\multicolumn{2}{|c|}{$\begin{array}{l}\text { Categorical variables / characteristics of the mother } \\
\text { and child }\end{array}$}} & \multicolumn{2}{|c|}{$\begin{array}{c}\text { Complete } \\
\text { Vaccination }\end{array}$} & \multirow[b]{2}{*}{ Total } & \multicolumn{2}{|c|}{ Binary logistic } \\
\hline & & & \multirow{2}{*}{$\begin{array}{c}\text { Yes } \\
\mathrm{N}=96 \\
(\%)\end{array}$} & \multirow{2}{*}{$\begin{array}{c}\text { No } \\
\mathrm{N}=64 \\
(\%)\end{array}$} & & \multirow[t]{2}{*}{ OR $(95 \% \mathrm{CI})$} & \multirow[t]{2}{*}{$\begin{array}{c}\text { P. } \\
\text { Value }\end{array}$} \\
\hline & & & & & $\begin{array}{c}\mathrm{N}=160 \\
(\%)\end{array}$ & & \\
\hline \multirow[t]{6}{*}{ Maternal Age } & \multirow[t]{2}{*}{$<25$} & Yes & $\begin{array}{c}53 \\
(60.9)\end{array}$ & $\begin{array}{c}34 \\
(39.1)\end{array}$ & $\begin{array}{c}87(54.4 \\
)\end{array}$ & $\begin{array}{c}1.09(0.57- \\
2.05)\end{array}$ & 0.461 \\
\hline & & No & $\begin{array}{c}43 \\
(58.9)\end{array}$ & $\begin{array}{c}30 \\
(41.1)\end{array}$ & $\begin{array}{c}73(45.6 \\
)\end{array}$ & & \\
\hline & \multirow[t]{2}{*}{25 to 34} & Yes & $33(60)$ & $22(40)$ & $\begin{array}{c}55(34.4 \\
)\end{array}$ & $1(0.51-1.94)$ & 0.566 \\
\hline & & No & $63(60)$ & $42(40)$ & $\begin{array}{c}105 \\
(65.6)\end{array}$ & & \\
\hline & \multirow[t]{2}{*}{$>34$} & Yes & $\begin{array}{c}10 \\
(55.6)\end{array}$ & $8(44.4$ & $\begin{array}{c}18(11.3 \\
)\end{array}$ & $\begin{array}{c}0.81(0.30- \\
2.18)\end{array}$ & 0.434 \\
\hline & & No & $\begin{array}{c}86 \\
(60.6)\end{array}$ & $\begin{array}{c}56 \\
(39.4)\end{array}$ & $\begin{array}{c}142 \\
(88.8)\end{array}$ & & \\
\hline \multirow[t]{8}{*}{ Education } & \multirow[t]{2}{*}{ No school } & Yes & $0(0)$ & $2(100)$ & $2(1.3)$ & 0 & 0.158 \\
\hline & & No & $\begin{array}{c}96 \\
(60.8)\end{array}$ & $\begin{array}{c}62 \\
(39.2)\end{array}$ & $\begin{array}{c}158 \\
(98.8)\end{array}$ & & \\
\hline & \multirow[t]{2}{*}{ Primary } & Yes & $\begin{array}{c}37 \\
(54.4)\end{array}$ & $\begin{array}{c}31 \\
(45.6)\end{array}$ & $\begin{array}{c}68(42.5 \\
)\end{array}$ & $\begin{array}{c}0.67(0.35- \\
1.26)\end{array}$ & 0.141 \\
\hline & & No & $\begin{array}{c}59 \\
(64.1)\end{array}$ & $\begin{array}{c}33 \\
(35.9)\end{array}$ & $\begin{array}{c}92(57.5 \\
)\end{array}$ & & \\
\hline & \multirow[t]{2}{*}{ Secondary } & Yes & $\begin{array}{c}57 \\
(64.8)\end{array}$ & $\begin{array}{c}31 \\
(35.2)\end{array}$ & $88(55)$ & $\begin{array}{c}1.55(0.82- \\
2.94)\end{array}$ & 0.115 \\
\hline & & No & $\begin{array}{c}39 \\
(54.2)\end{array}$ & $\begin{array}{c}33 \\
(45.8)\end{array}$ & $72(45)$ & & \\
\hline & \multirow[t]{2}{*}{ University } & Yes & $2(100)$ & 0 & $2(1.3)$ & & 0.36 \\
\hline & & No & $\begin{array}{c}94 \\
(59.5)\end{array}$ & $\begin{array}{c}64 \\
(40.5)\end{array}$ & $\begin{array}{c}15(98.8 \\
)\end{array}$ & & \\
\hline \multirow[t]{8}{*}{ Child Birth order } & \multirow[t]{2}{*}{1 st } & Yes & $\begin{array}{c}27 \\
(67.5)\end{array}$ & $\begin{array}{c}13 \\
(32.5)\end{array}$ & $40(25)$ & $\begin{array}{c}1.53(0.72- \\
3.26)\end{array}$ & 0.176 \\
\hline & & No & $\begin{array}{c}69 \\
(57.5) \\
\end{array}$ & $\begin{array}{c}51 \\
(42.5) \\
\end{array}$ & $120(75)$ & & \\
\hline & \multirow[t]{2}{*}{ 2nd } & Yes & $\begin{array}{c}32 \\
(68.1) \\
\end{array}$ & $\begin{array}{c}15 \\
(31.9) \\
\end{array}$ & $\begin{array}{c}47(29.4 \\
) \\
\end{array}$ & $\begin{array}{c}1.63(0.79- \\
3.34) \\
\end{array}$ & 0.121 \\
\hline & & No & $\begin{array}{c}64 \\
(56.6) \\
\end{array}$ & $\begin{array}{c}49 \\
(43.4) \\
\end{array}$ & $\begin{array}{c}113 \\
(70.6) \\
\end{array}$ & & \\
\hline & \multirow[t]{2}{*}{3 rd } & Yes & $14(50)$ & $14(50)$ & $\begin{array}{c}28(17.5 \\
)\end{array}$ & $\begin{array}{c}0.61(0.26- \\
1.38)\end{array}$ & 0.164 \\
\hline & & No & $\begin{array}{c}82 \\
(62.1) \\
\end{array}$ & $\begin{array}{c}50 \\
(37.9) \\
\end{array}$ & $\begin{array}{r}132( \\
82.5) \\
\end{array}$ & & \\
\hline & \multirow[t]{2}{*}{$>3$} & Yes & $\begin{array}{c}23 \\
(51.1) \\
\end{array}$ & $\begin{array}{c}22 \\
(48.9) \\
\end{array}$ & $\begin{array}{c}45(28.1 \\
)\end{array}$ & $\begin{array}{c}0.6(0.29- \\
1.20)\end{array}$ & 0.105 \\
\hline & & No & $\begin{array}{c}73 \\
(63.5)\end{array}$ & $\begin{array}{c}42 \\
(36.5)\end{array}$ & $\begin{array}{c}115 \\
(71.9)\end{array}$ & & \\
\hline \multirow[t]{2}{*}{ Marital Status } & \multirow[t]{2}{*}{ Single } & Yes & $17(81)$ & $4(19)$ & $\begin{array}{c}21(13.1 \\
) \\
\end{array}$ & $\begin{array}{c}3.23(1.03- \\
10.09)\end{array}$ & 0.028 \\
\hline & & No & $\begin{array}{r}79( \\
56.8)\end{array}$ & $\begin{array}{c}60 \\
(43.2)\end{array}$ & $\begin{array}{c}139 \\
(86.9)\end{array}$ & & \\
\hline
\end{tabular}




\begin{tabular}{|c|c|c|c|c|c|c|c|}
\hline & \multirow[t]{2}{*}{ Married } & Yes & $\begin{array}{c}79 \\
(57.2)\end{array}$ & $\begin{array}{c}59 \\
(42.8)\end{array}$ & $\begin{array}{c}138 \\
(86.3)\end{array}$ & $\begin{array}{c}0.393(0.13- \\
1.12)\end{array}$ & 0.06 \\
\hline & & No & $\begin{array}{c}17 \\
(77.3)\end{array}$ & $\begin{array}{c}5(22.7 \\
)\end{array}$ & $\begin{array}{c}22(13.8 \\
)\end{array}$ & & \\
\hline & \multirow[t]{2}{*}{ Widow } & Yes & 0 & $1(100)$ & $1(0.6)$ & 0 & 0.4 \\
\hline & & No & $\begin{array}{c}96 \\
(60.4)\end{array}$ & $\begin{array}{c}63 \\
(39.6)\end{array}$ & $\begin{array}{c}159 \\
(99.4)\end{array}$ & & \\
\hline & Divorced & No & $96(60)$ & $64(40)$ & $\begin{array}{c}160 \\
(100)\end{array}$ & & \\
\hline \multirow[t]{7}{*}{ Religion } & \multirow[t]{2}{*}{ Catholic } & Yes & $12(75)$ & $4(25)$ & $16(10)$ & $\begin{array}{c}2.14(0.65- \\
6.96)\end{array}$ & 0.1533 \\
\hline & & No & $\begin{array}{c}84 \\
(58.3)\end{array}$ & $\begin{array}{c}60 \\
(41.7)\end{array}$ & $144(90)$ & & \\
\hline & \multirow[t]{2}{*}{ Protestant } & Yes & $\begin{array}{c}24 \\
(82.8) \\
\end{array}$ & $\begin{array}{c}5(17.2 \\
)\end{array}$ & $\begin{array}{c}29(18.1 \\
)\end{array}$ & $\begin{array}{c}3.93(1.41- \\
10.94)\end{array}$ & 0.004 \\
\hline & & No & $72(55)$ & $59(45)$ & $\begin{array}{c}131 \\
(81.9)\end{array}$ & & \\
\hline & \multirow[t]{2}{*}{ Muslim } & Yes & $\begin{array}{c}60 \\
(52.2)\end{array}$ & $\begin{array}{c}55 \\
(47.8)\end{array}$ & $\begin{array}{c}115 \\
(71.9)\end{array}$ & $\begin{array}{c}0.27(0.12- \\
0.61)\end{array}$ & 0.001 \\
\hline & & No & $36(80)$ & $9(20)$ & $\begin{array}{c}45(28.1 \\
) \\
\end{array}$ & & \\
\hline & Animist & No & $96(60)$ & $64(40)$ & $\begin{array}{l}160 \\
(100)\end{array}$ & & \\
\hline \multirow[t]{4}{*}{ Occupations } & \multirow[t]{2}{*}{ Formal sector } & Yes & $\begin{array}{c}8(66.7 \\
) \\
\end{array}$ & $\begin{array}{c}4(33.3 \\
) \\
\end{array}$ & $12(7.5)$ & $\begin{array}{c}1.36(0.39- \\
4.73)\end{array}$ & 0.434 \\
\hline & & No & $\begin{array}{c}88 \\
(59.5)\end{array}$ & $\begin{array}{c}60 \\
(40.5)\end{array}$ & $\begin{array}{c}148 \\
(92.5)\end{array}$ & & \\
\hline & \multirow[t]{2}{*}{ Informal Sector } & Yes & $\begin{array}{c}88 \\
(59.5)\end{array}$ & $\begin{array}{c}60 \\
(40.5)\end{array}$ & $\begin{array}{c}148 \\
(92.5)\end{array}$ & $\begin{array}{c}0.73(0.21- \\
2.54)\end{array}$ & 0.434 \\
\hline & & No & $\begin{array}{c}8(66.7 \\
)\end{array}$ & $\begin{array}{c}4(33.3 \\
\text { ) } \\
\end{array}$ & $12(7.5)$ & & \\
\hline \multirow[t]{6}{*}{ Reason for vaccinating } & \multirow[t]{2}{*}{ Prevent the occurrence of diseases } & Yes & $\begin{array}{c}64 \\
(58.7) \\
\end{array}$ & $\begin{array}{r}45 \\
(41.3) \\
\end{array}$ & $\begin{array}{r}109 \\
(68.1) \\
\end{array}$ & $\begin{array}{c}0.84(0.42- \\
1.67) \\
\end{array}$ & 0.379 \\
\hline & & No & $\begin{array}{c}32 \\
(62.7) \\
\end{array}$ & $\begin{array}{c}19 \\
(37.3) \\
\end{array}$ & $\begin{array}{c}51(31.9 \\
) \\
\end{array}$ & & \\
\hline & \multirow[t]{2}{*}{ Decrease the severity of diseases } & Yes & $1(50)$ & $1(50)$ & $2(1.2)$ & $\begin{array}{c}0.66(0.04- \\
10.79)\end{array}$ & 0.641 \\
\hline & & No & $\begin{array}{r}95 \\
(60.1) \\
\end{array}$ & $\begin{array}{c}63 \\
(39.9) \\
\end{array}$ & $\begin{array}{r}158 \\
(98.8) \\
\end{array}$ & & \\
\hline & \multirow[t]{2}{*}{ No idea } & Yes & $\begin{array}{c}31 \\
(63.3) \\
\end{array}$ & $\begin{array}{c}18 \\
(36.7) \\
\end{array}$ & $\begin{array}{c}49\left(\begin{array}{c}30.6 \\
)\end{array}\right. \\
\end{array}$ & $1.2(0.61-2.4)$ & 0.35 \\
\hline & & No & $\begin{array}{r}65 \\
(58.6) \\
\end{array}$ & $\begin{array}{c}46 \\
(41.4) \\
\end{array}$ & $\begin{array}{r}111 \\
(69.4) \\
\end{array}$ & & \\
\hline \multirow[t]{4}{*}{$\begin{array}{c}\text { Knowledge of VDP and infectious } \\
\text { diseases }\end{array}$} & \multirow[t]{2}{*}{ Good knowledge } & Yes & $\begin{array}{c}88 \\
(63.7) \\
\end{array}$ & $\begin{array}{c}50 \\
(36.2) \\
\end{array}$ & $\begin{array}{c}138 \\
(86.2)\end{array}$ & $\begin{array}{c}3.08(1.21- \\
7.85) \\
\end{array}$ & 0.01 \\
\hline & & No & $\begin{array}{c}8(36.3 \\
)\end{array}$ & $\begin{array}{c}14 \\
(63.6)\end{array}$ & $22(13.8)$ & & \\
\hline & \multirow[t]{2}{*}{ Poor knowledge } & Yes & $8(36.4)$ & $\begin{array}{c}14 \\
(63.6) \\
\end{array}$ & $22(13.8)$ & $\begin{array}{c}0.32(0.12- \\
0.82)\end{array}$ & 0.014 \\
\hline & & No & $\begin{array}{c}88 \\
(63.8) \\
\end{array}$ & $\begin{array}{c}50 \\
(36.2)\end{array}$ & $\begin{array}{c}138 \\
(86.3)\end{array}$ & & \\
\hline Age-appropriate vaccination & At Birth & Yes & 83 & 46 & 129 & 2.5 (1.12 - & 0.02 \\
\hline
\end{tabular}




\begin{tabular}{|c|c|c|c|c|c|c|c|}
\hline & & & $(64.3)$ & $(35.7)$ & $(80.6)$ & 5.55) & \\
\hline & & No & $\begin{array}{c}13 \\
(41.9)\end{array}$ & $\begin{array}{c}18 \\
(58.1)\end{array}$ & $\begin{array}{c}31(19.4 \\
)\end{array}$ & & \\
\hline & \multirow[t]{2}{*}{ No idea } & Yes & $11(44)$ & $14(56)$ & $\begin{array}{c}25(15.6 \\
)\end{array}$ & $\begin{array}{c}0.4(0.19- \\
1.09)\end{array}$ & 0.06 \\
\hline & & No & 85 (63) & 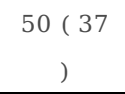 & $\begin{array}{r}135 \\
(84.3)\end{array}$ & & \\
\hline & \multirow[t]{2}{*}{ Other date } & Yes & $2(33.3)$ & 4 (66.6) & $6(3.7)$ & $\begin{array}{c}0.32(0.06- \\
1.79)\end{array}$ & 0.17 \\
\hline & & No & $94(60)$ & $60(40)$ & $\begin{array}{c}154 \\
(96.9)\end{array}$ & & \\
\hline \multirow[t]{2}{*}{$\begin{array}{l}\text { Mastering of the vaccination } \\
\text { schedule }\end{array}$} & \multirow[t]{2}{*}{ Master } & Yes & $\begin{array}{c}29 \\
(80.6)\end{array}$ & $\begin{array}{c}7(19.4 \\
)\end{array}$ & $\begin{array}{c}36(22.5 \\
)\end{array}$ & $\begin{array}{c}3.52(1.43- \\
8.65)\end{array}$ & 0.002 \\
\hline & & No & $67(54)$ & $57(46)$ & $\begin{array}{c}124 \\
(77.5) \\
\end{array}$ & & \\
\hline \multirow[t]{2}{*}{$\begin{array}{c}\text { Retention of the vaccination } \\
\text { booklet }\end{array}$} & \multirow[t]{2}{*}{ Keep } & Yes & 88 (62) & 54 (38) & $\begin{array}{c}142 \\
(88.8) \\
\end{array}$ & $\begin{array}{c}2.04(0.76- \\
5.48) \\
\end{array}$ & 0.121 \\
\hline & & No & $\begin{array}{c}8(44.4 \\
)\end{array}$ & $\begin{array}{c}10 \\
(55.6)\end{array}$ & $\begin{array}{c}18(11.3 \\
)\end{array}$ & & \\
\hline
\end{tabular}

Table 3: Sociodemographic characteristics and complete childhood vaccination in Foumbot district, 2014

\begin{tabular}{|c|c|c|c|}
\hline \multicolumn{2}{|c|}{ The child was not completely vaccinated because of: } & \multirow{2}{*}{$\begin{array}{c}\text { cases } \\
6\end{array}$} & \multirow{2}{*}{$\begin{array}{c}\text { Percentage } \\
17 \%\end{array}$} \\
\hline Missing Information & Ignores the necessity for vaccination & & \\
\hline & Ignores the necessity of the $2 \mathrm{nd}$ and 3 rd dose & 3 & \\
\hline & Fear of adverse effects & 2 & \\
\hline \multirow[t]{2}{*}{ No interest } & Discouraged by the entourage & 2 & \multirow[t]{2}{*}{$6.25 \%$} \\
\hline & Does not trust vaccination & 2 & \\
\hline \multirow[t]{7}{*}{ Lack of flexibility and resource } & Absence of the vaccination personal & 1 & \multirow[t]{7}{*}{$76.5 \%$} \\
\hline & Lack of financial means & 1 & \\
\hline & Vaccines not available & 4 & \\
\hline & Long waiting time & 3 & \\
\hline & Not suitable time schedule & 1 & \\
\hline & Impediment (travel, sickness, mourning) & 33 & \\
\hline & Lack of time & 6 & \\
\hline \multicolumn{2}{|r|}{ Total } & 64 & $100 \%$ \\
\hline
\end{tabular}

Table 4: Reasons given by parents for missing the vaccination

\section{Parental Perception}

\section{Defaulting factors}

The parents whose children had not completed the EPI mentioned missing information (17\%), Lack of interest (6.2\%), and lack of flexibility and resource (76.5) [Table 4]. 
The association of the sociodemographic factors with completion of child vaccination were assessed by this study. The results showed that $52 \%$ and $80 \%$ of those who are Muslim and Non-Muslim, respectively, had children with complete vaccination status, whereas $48 \%$ and $20 \%$ of those who are Muslim and nonMuslim, respectively, had children with partial vaccination status. From all the variables, religious belonging (Muslim) showed significant association with incompletion of vaccination in bivariate analysis. The likelihood of vaccination completion among parents in Muslim communities was about $27 \%(\mathrm{OR}=0.27$; $\mathrm{p}$-value $<0.05)$ when compared with parents in other religious communities [Table 3].

Furthermore, the results showed that $36 \%$ and $64 \%$ of those with poor knowledge of VPDs and good knowledge of VPDs, respectively, had their children with complete vaccination status, whereas $54 \%$ and $36 \%$ of those with poor knowledge of VPDs and good knowledge of VPDs, respectively had their children with partial vaccination status or no vaccination status. The statistics showed that there was significant association between poor knowledge of VPDs and the childhood vaccination status [OR $=0.32$ ] at $p$-value $<0.05$ [Table 3].

\section{Parents' decision making}

Of all parents whose children had complete vaccination status, $64: 3 \%$ were assigned to the group of parents who started the vaccination at birth, $63.7 \%$ were assigned to the group of parents with good knowledge of VPDs, and $80 \%$ were assigned to the group of parents who mastered the vaccination schedule. The statistics showed that starting vaccination at birth [OR=2.5], knowledge of VPDs [OR=3.08], and mastering the vaccination schedule [OR $=3.52$ ] were significantly positive associated with complete childhood vaccination. The result of the logistic regression analysis are showed in Table 5. The final model (step 3) shows the smallest value of the AIC, the BIC, and the -2 Log Likelihood statistics [Table 5]. This model (step 3 ) is better suited to explain the decision of parents about childhood vaccination status. After the adjustment of all variables that were found significant, poor knowledge of VPDs was found as a significant negative predictor of the intention to complete the EPI. That is, poor knowledge of VPDs significantly predicted a lower likelihood for parents to complete the EPI.

\begin{tabular}{|l|l|l|l|l|l|l|l|c|}
\hline \multirow{2}{*}{} & Action & Effect(s) & \multicolumn{2}{l|}{ Model Fitting Criteria } & \multicolumn{2}{l|}{ Effect Selection Tests } \\
\cline { 4 - 9 } Model & & & AIC & BIC & $\begin{array}{l}\text {-2Log- } \\
\text { Likelihood }\end{array}$ & $\begin{array}{l}\text { Chi- } \\
\text { square }\end{array}$ & $\begin{array}{l}\text { degree } \\
\text { freedom }\end{array}$ & Significance \\
\hline Step 0 & Entered & Constant & 85.70 & 88.78 & 83.70 & & & \\
\hline Step 1 & Entered & Muslim & 76.58 & 82.73 & 72.58 & 11.12 & 1 & 0.001 \\
\hline Step 2 & Entered & Start at birth & 67.74 & 76.97 & 61.74 & 10.84 & 1 & 0.001 \\
\hline Step 3 & Entered & $\begin{array}{c}\text { Poor Knowledge of } \\
\text { VPDs }\end{array}$ & 64.16 & 76.46 & 56.14 & 5.58 & 1 & 0.018 \\
\hline
\end{tabular}

Stepwise Method: Forward Selection

a. The Chi-Square for entry is based on the Likelihood-Ratio-Test

Table 5: Step Summary - Information criteria

Page 10/19 


\section{Discussion}

This study examined the association and influence of sociodemographic factors, knowledge of VPDs to complete childhood vaccination.

In this study, $76.5 \%$ of the parents whose children did not complete the EPI mentioned barriers linked to flexibility and resource [Table 4]. Referring to Table 2, some health facilities had only 1 or 2 persons in charge of the vaccination. In 2015, Cameroon was still classified by the WHO as having an acute shortage of health personnel [38]. Researchers in the USA and in Vietnam observed that the advice of a healthcare professional was the major factor that changed the view of parents who had previously refused to let their children be vaccinated or had delayed vaccination [39][40]. Therefore, contact with a healthcare professional is an important factor in health decision-making. The results of this study show that starting at birth the vaccination program increased by 2.5 the likelihood to complete the EPI [OR=2.5] [Table 3]. A study performed in 2000 in a rural community in Edo State in Nigeria showed that early vaccination of children increases the awareness of the parents towards VPDs and vaccination [36]. Administering the first vaccine at birth is an important step for building confidence in the medical system and in raising parental awareness about VPDs and the role that the vaccination can play in promoting the child's health. However, we found that only $60 \%$ of children had completed the EPI at the age of two years, although $98 \%$ of the children had received the BCG vaccine at birth. This shows that the awareness towards VPDs has not been reached and the confidence in the medical system was not established. A poor knowledge of VPDs [OR=0.32] was identified as the predictor of failure of complete vaccination in children. Additionally, it was found that in the group of parents belonging to Islam, $47.8 \%$ of the parents failed to complete the EPI while $20 \%$ were reported in other religious groups [Table 3]. The failure in the vaccination programs in Muslim communities has been reported in Nigeria, Pakistan, and Afghanistan. [13][15][20][21]. In these countries, parents' decision-making was guided by the propaganda against polio vaccine by Muslim fundamentalists. Just like Muslim communities, African communities are regularly affected by negative information on vaccination programs so that medical interventions intersected with cultural perceptions [13]. Most people on the African continent and particularly in rural areas like the Foumbot district cannot identify with the vaccination [14][35][46]. Consequently, fear "makes sense" [19] [35]. The perception of parents living in these communities regarding vaccination is likely to turn into refusal following stories often linked to a conspiracy theory [13][15][20][21]. Because of the slave trade and colonization, many Africans and particularly Muslims are skeptical and suspicious about any intervention from western countries and those who refuse vaccination perceive the EPI as a western propaganda to destroy Africans, Muslims and their local traditions and cultures [34]. This outcome shows that parents' perception regarding vaccination was not generated by the religious principles but by how the information available in the community is perceived and understood. Data from India, Nigeria, and the United Kingdom (UK) shows that for these countries, trust in immunization programs is more often associated with trust in health systems [37][47]. In 2003, negative information affected the vaccination program in Muslim communities in Nigeria negatively [13][19][21]. In order to regain confidence, a longterm program was put in place. This program involved different actions and key players to help build support for vaccination: grassroots involvement, change of initiatives, and public and media awareness 
[20][33]. In this study, parents with good knowledge of VPDs had a higher likelihood to complete the EPI $[O R=3.08]$. Therefore, vaccination coverage increases as parents' knowledge of VPDs increases. This result is similar to studies carried out in Kenya, Nigeria, Senegal, and Turkey where it was found that educating parents particularly on healthcare and on programs to improve quality of life has reduced child mortality and increased life expectancy [16][15][41][42][43]. From these results, health education programs are beneficial as they enable parents to receive knowledge of diseases, healthcare, and prevention. It is not about academic qualification, which assures only that an individual has learned the theory and, acquired knowledge but does not guarantee that the individual has developed skills to adopt and to implement the knowledge in real life. In Thailand, it was found that women who attended a community empowerment program implemented plans to fight against malaria [44]. They offered malaria education to community members, taught mosquito control actions, promoted the use of insecticide treated bed nets, and also initiated entrepreneurship to increase revenue for the family. In Papua New Guinea, a program empowered members of a community to take charge of the acquisition, distribution and effective utilization of bed nets [44]. This led to a significant reduction in the incidence of mortality linked to malaria. Health education should ensure that parents acquire the knowledge of diseases, their causes and consequences, and learn about healthcare with the goal to engage and invest in personal and community health.

\section{Limitations Of The Study}

In this study, some limitations were expected because this is a cross-sectional study, and the sampling method is susceptible to selection bias. Only the participants that were present in the district at the time of the interview and that met the survey inclusion criteria were considered in the sample.

\section{Conclusions}

"It is often not just what is offered that makes bait out, but how it is perceived by the recipient matters" Simmi Oberoi et al. 2016

This study identified predictors of childhood vaccination hesitancy and suggestions were made to support parents' decision-making for childhood immunization and prevention of childhood diseases.

The factors "poor knowledge of VPDs and infectious diseases" and "belonging to Islam" were found to be statistically significant and associated with the failure in childhood vaccination [Table 3]. Although Islam itself is not against the vaccination, it was noticed that negative information about vaccination is frequently spread around in Muslim communities [13][21]. The shortage of health personnel in the Foumbot district [Table 2] and in Cameroon in general also limits the populations' access to health information and the trust in the medical system. When parents have poor knowledge of VPDs and the confidence in the medical system is not established, they are expected not to trust in the vaccination and in turn to refuse or interrupt the EPI. On the other hand, the factors "good knowledge of VPDs and infectious diseases" and starting vaccination "at birth" were found to be statistically significant and 
positively associated with complete childhood vaccination [Table 3]. These two factors were advantageous to establish trust in the EPI and therefore generate in parents the perceptions "demand" or "acceptance" of the childhood vaccination. In the literature "Patterns of vaccination acceptance", Streefland et al [32] declared that the perceptions demand, acceptance and refusal may or may not be based on a knowledgeable comprehension of the vaccination but are based on the experience people or communities have with it. Following this declaration, this study has found that decision-making by parents regarding vaccination may or may not be based directly on sociodemographic factors but are based on the experience and the interpretation by the local value system of the existing information available in the community [Figure 1]. The findings of this study suggest investing in health education programs targeted at parents who are poorly educated on infectious diseases. These programs should not be limited to how to avoid illness or how to cope with diseases. It should also focus on the understanding of peoples' local health beliefs and practices and consider these beliefs and practices in developing health education programs with the purpose of developing skills in health-seeking behavior in individuals and communities. Based on the outcomes of this study, a community-related framework [Figure 1] has been developed using the conceptual framework of Sturm et al and in accordance with the Health Belief Model (HBM) [25][26]. Future research should investigate possibilities in understanding the dynamics of communities regarding health issues, while tailoring immunization programs to the local context.

\section{List Of Abbreviations}




\begin{tabular}{ll}
\hline AIC & Akaike's Information Criterion \\
\hline AIDS & Acquired Immune Deficiency Syndrome \\
\hline AUC & Area Under the Curve \\
\hline BCG & Bacillus Calmatte Guiren \\
\hline BIC & Bayesian Information Criterion \\
\hline Cl & Confidence Interval \\
\hline CIA & Central Intelligence Agency \\
\hline CMYP & Comprehensive Multiyear Plan \\
\hline df & Degree of freedom \\
\hline DPT & Diphtheria, Pertussis, Tetanus \\
\hline EBM & Evidence Based Medicine \\
\hline ECDC & European Centre for Disease Prevention and Control \\
\hline EPI & Expanded Program on Immunization \\
\hline EXP & Exponential \\
\hline GPEI & Global Polio Eradication Initiative \\
\hline GVAP & Global Vaccine Action Plan \\
\hline HBM & Health-Belief-Model \\
\hline Hib & Haemophilus influenza type b \\
\hline HIV & Human Immunodeficiency Virus \\
\hline MCV & Measles-Containing vaccine \\
\hline MDO & Millennium Development Objectives \\
\hline MMR & Measles, Mumps and Rubella vaccine \\
\hline NGO & Non-government Organization \\
\hline NID & National Immunization Day \\
\hline OPV & Oral Polio Vaccine \\
\hline OR & Odds Ratio \\
\hline Poference \\
\hline Poumococcal Conjugate Vaccine \\
\hline Polio
\end{tabular}




\begin{tabular}{ll} 
ROC & Receiver Operating Characteristic \\
\hline S.E. & Standard Error \\
\hline Sig. & Significance \\
\hline SRS & Simple random sample \\
\hline TT & Tetanus Toxoid \\
\hline UN & United Nations \\
\hline UNICEF & United Nations Children's Fund \\
\hline USA & United States of America \\
\hline VAA & Vaccin Anti Amaril (yellow fever vaccine) \\
\hline VAR & Vaccin Anti Rougeoleux (measles vaccine) \\
\hline WHA & World Health Assembly \\
\hline VPD & vaccine preventable disease \\
\hline WHO & World Health Organization \\
\hline WPV & Wild Poliomyelitis Virus
\end{tabular}

\section{Declarations}

\section{- Ethics approval and consent to participate}

The ethical approval Autorisation $N^{\circ} 2014 / 036 / U d M / P R / C A B / C I E$ was obtained on the 30th June 2014 from the Institutional Ethic Committee of the Université des Montagnes. Before data collection, written consent was obtained from the respondents. No participant was below the age of 16 at the time of the study.

\section{- Consent for publication}

Not applicable

\section{- Availability of data and materials}

The datasets used and/or analyzed during the current study are available from the corresponding author on reasonable request.

\section{- Competing interests}

The authors declare that they have no competing interests. 
- Funding

Not applicable

\section{- Authors' contributions}

JK was involved in the conception, design, analysis and interpretation of data, and report writing.

AL has been involved in the conception, design, analysis of the data and critically reviewed the manuscript.

TO has assisted with the conception and designing the study and critically reviewed the manuscript VK was involved in the interview process and the collect of the data.

All authors read and approved the final manuscript

\section{- Acknowledgements}

Not applicable

\section{References}

1. Riedel S, (2005), Edward Jenner and the history of smallpox and vaccination.

2. WHO Western Pacific Region. 2017. WPRO / Expanded program on immunization (EPI). [ONLINE] Available at: http://www.wpro.who.int/immunization/en/. [Accessed 26 October 2017].

3. World Health Organization. 2017. WHO / Measles vaccination has saved an estimated 17.1 million lives since 2000. [ONLINE] Available at: http://www.who.int/mediacentre/news/releases/2015/measles-vaccination/en/. [Accessed 26 October 2017].

4. World Health Organization, UNICEF, (2005), Global Vaccination Vision and Strategy 2006-2015. Geneva, Switzerland: World Health Organization.

5. World Health Organization, (2005), Vaccination coverage cluster survey reference manual WHO/IVB/04.23

6. World Health Organization, (2008), The EPI coverage survey - WHO/IVB/08.07

7. Institut National de la Statistique Cameroun, (2011), Document de méthodologie de l'enquête sur les connaissances, attitudes et pratiques des populations en matière de vaccination au Cameroun en 2011: CAP 2011

8. SCHWARTZ D, (1969), Méthodes statistiques à l'usage des médecins et biologistes. 
9. United Nations, (2005), Designing Household Survey Samples: Practical Guidelines

10. S. Bennett, T. Woods, W. Liyanage, D. Smith, (1991), A simplified general method for cluster sample surveys of health in developing countries -

11. Cameroon Ministry of public Health, (2011), Cameroun-Comprehensive multi-year plan for 2011-2015

12. DREF operation $\mathrm{N}^{\circ}$. MDRCM30; November, 2013

13. Kapp C, (2003), Surge in polio spreads alarm in northern Nigeria. Rumours about vaccine safety in Muslim-run states threaten WHO's eradication program. Lancet

14. Ambe, Omotara, (2001), Perceptions, beliefs and practices of mothers in sub-urban and rural areas towards measles and measles vaccination in Northern Nigeria.

15. Olumuyiwa O Odusanya, Ewan F Alufohai, Francois P Meurice and Vincent I Ahonkhai, (2008), The determinants of vaccination coverage in rural Nigeria. BMC Public Health

16. Ndèye Magatte, Ndiaye Papa Ndiaye, Abdoulaye Diedhiou, Abdou Salam Gueye, Anta TalDia. Cahiers Santé, (2009), Facteurs d'abandon de la vaccination des enfants âgés de 10 à 23 mois à Ndoulo au Sénégal en 2005.

17. Belachew Etana, (2011), Factors Affecting Immunization Status of Children Aged 12-23 Months in Ambo Woreda, West Shewa Zone of Oromia Regional State Ethiopia 2011. Thèse master en santé publique, School of Public Health. Addis Abeba University

18. Abdulraheem I, Onajole A, Jimoh A and Oladipo A., (2011), Reasons for incomplete vaccination and factors for missed opportunities among rural Nigerian children. Journal of Public Health and Epidemiology.

19. IRIN, (2013), NIGERIA: Muslim suspicion of polio vaccine lingers on

20. Associated Press, (2015), Muslim Clerics Finally Embrace Polio Campaign - Retrieved

21. HaiderJ. Warraich, (2009), Religious Opposition to Polio Vaccination

22. Centers for Disease Control and Prevention, (2013), Global Routine Vaccination Coverage, 2014, MMWR (Morbidity and Mortality Weekly Report)

23. Prof. Robinson MBU, Ministry of public health Cameroon, (2014), Independent Monitoring Board (IMB) Global Polio Eradication Initiative (GPEI) Eleventh meeting London.

24. Cameroon WHO office, (2013), Annual Report 2012, 2013

25. Sturm LA, Mays RM, Zimet GD, (2005),Parental beliefs and decision-making about child and adolescent immunization, Pediatr 26:441-52

26. Sharon Teitler-Regev, (2011), Factors Affecting Intention among Students to Be vaccinated against A/H1N1 Influenza: A Health Belief Model Approach

27. Minsante Cameroun, (2015), Cameroun, Enquete par grappes à indicateurs multiples (MICS5) 2014, Rapport de résultats clés

28. Institut National de la statistique (INS) (Cameroun), 2005, Enquête Démographique et de Santé et à indicateurs multiples, Cameroun

29. Balinska M, Leon C, (2007), Opinions et réticences face à la vaccination 
30. Streefland PH, Chowdhury AM, Ramos-Jimenez P, (1999), Quality of vaccination services and social demand for vaccination in Africa and Asia

31. Gellin BG, Schaffner W: (2002), The risk of vaccination - the importance of "negative" studies

32. Streefland P, Chowdhury AMR, and Ramos-Jimenez P, (1999), Patterns of vaccination acceptance.

33. Nichter M, (1998) Special issue on the Debate on Selective or Comprehensive Primary Health Care

34. Stilwell S, (2002), The Imposition of Colonial Rule, Vol. 3, in Colonial Africa

35. Langwick SA, (2011), Bodies, Politics, and African Healing: The Matter of Maladies in Tanzania

36. O. O. Odusanya, (2000), Age-Appropriate Immunization Coverage in a Rural community in Edo State, Nigeria

37. Jonathan E Suk, Pierluigi Lopalco, (2015), Hesitancy, Trust and Individualism in Vaccination Decision-Making

38. Tandi et al., (2015), Cameroon public health sector: shortage and inequalities in geographic distribution of health personnel.

39. Gust, D. et al., (2008), "Parents with doubts about vaccines: Which vaccines and reasons why." Pediatrics

40. Dinh TA, Rosenthal SL, Doan ED, Trang T, Pham VH et al.,(2007), Attitudes of mothers in Da Nang, Vietnam toward a human papillomavirus vaccine

41. Elijah O. Onsomu, (2015), Maternal Education and Immunization Status Among Children in Kenya

42. B. Abuya, E.Onsomu, j. Kimani, (2011); Influence of Maternal Education on Child Immunization and Stunting in Kenya.

43. Torun SD, Bakirci N., (2006), Vaccination coverage and reasons for non-vaccination in a district of Istanbul. BMC Public Health

44. Sanjiv Kumar, GS Preetha, (2012), Health Promotion: An Effective Tool for Global Health

45. Vivian Lin et al., (2009), A Primer for Mainstreaming Health Promotion

46. M.G. Mokgobi, (2014), Understanding traditional African healing

47. Larson H, Schulz W, Tucker J, Smith DMD, (2015), Measuring Vaccine Confidence: Introducing a Global Vaccine Confidence Index

\section{Figures}




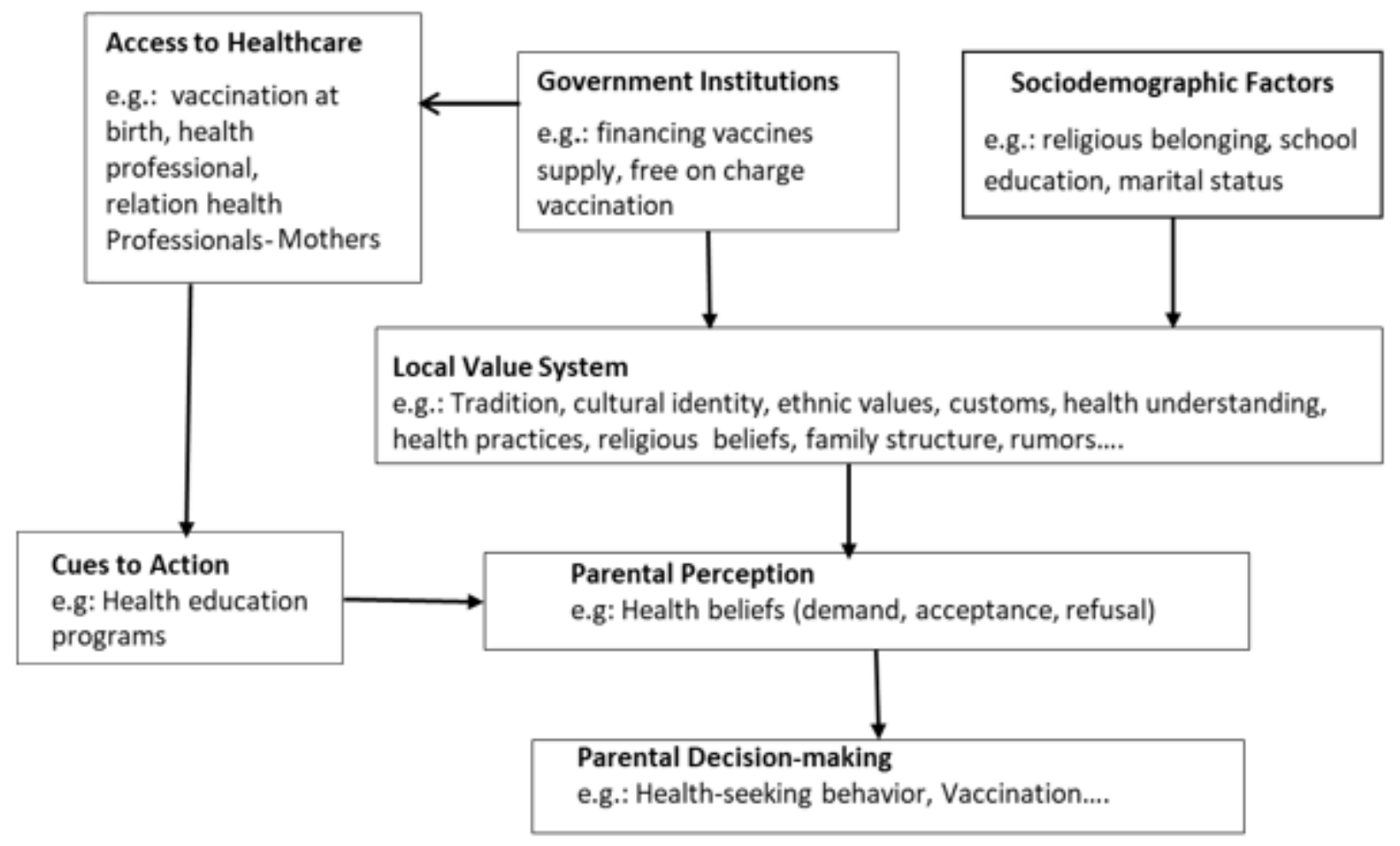

Figure 1

Community-related conceptual framework of parental decision-making

\section{Supplementary Files}

This is a list of supplementary files associated with this preprint. Click to download.

- TranlatedfromFrenchtoEnglishQuestionnaireFoumbot.pdf 